\title{
The Competitive Position of the Economy of Poland (against the Backdrop of the Visegrad Group Countries and the Baltic States) - Changes and Determinants in the Post-accession Period ${ }^{1}$
}

\author{
Edward Molendowski iD https://orcid.org/0000-0003-0803-1592 \\ Ph.D., University Professor, Cracow University of Economics \\ Department of International Economics, Cracow, Poland \\ e-mail: edward.molendowski@uek.krakow.pl
}

\begin{abstract}
The article presents the results of an analysis that compares changes in Poland's competitive position against the backdrop of the Visegrad Group (V4) countries and the Baltic States (BS3) in the post-accession period (2006-2017). This type of study has not been presented in detail in the available literature before. Therefore, the article may significantly contribute to bridging the gap.

The study employs a comparative analysis of secondary data concerning the indices and pillars of economic competitiveness described in The Global Competitiveness Reports prepared by the World Economic Forum. An important element of the examination was the endeavour to identify major determinants of those developments. The article ends with a summary of the most significant conclusions from the analysis presented. As confirmed by the examination, the countries covered differed widely regarding the improvement of their competitive positions in the post-accession period.
\end{abstract}

Keywords: international economic competitiveness, international competitiveness of an economy, effects of EU membership, Baltic States, Visegrad Group countries, Visegrad countries, new EU Member States

JEL: E2, E6, F4, F5

1 The publication was co-financed from funds allocated to the Cracow University of Economics as a subsidy for reinforcing research potential (within the framework of the Potencjat programme). 


\section{Introduction}

Thanks to their accession to the European Union (EU), the majority of the new Member States experienced rapid economic growth accompanied by restructuring and modernisation. It considerably improved the international competitive positions of their economies (for more on the subject see Molendowski 2015, pp. 5-18).

The article presents the results of an analysis that compares changes in the competitive position of Poland's economy against the backdrop of the Visegrad Group (V4) countries, i.e. Poland, Hungary, Slovakia, Czechia aswell as the Baltic States (BS3), i.e. Estonia, Lithuania, and Latvia, in the post-accession period (2004-2017). Among the countries under examination, Poland is considered to be one of the most successful in improving the competitive positions of their economies after joining the EU (Molendowski and Folfas 2019; Wołkonowski 2019).

The analysis was based on the indicators presented in The Global Competitiveness Reports prepared by the World Economic Forum. The reports contain some of the most comprehensive and most frequently quoted rankings of international economic competitiveness. The assumption is that the EU accession had a considerable impact on the development of the competitive position, but specific effects varied between countries. The examination also attempts to identify the influence of the most important factors (pillars) on the competitive positions of the countries covered in the period in question. According to the World Economic Forum experts, the countries in question should already be at a stage of building their competitive positions based on efficiency enhancers as well as on innovation and sophistication factors. The analysis presented in the article aims to verify that assumption.

This objective determined the structure of the article. The text begins with an introduction indicating the context and purpose of the study. The substantive part of the article is divided into four sections. The first section presents a review of major publications in the literature concerning the phenomenon of competitiveness and the international competitive position of an economy. Section two describes the measures and methods of measuring international economic competitiveness applied in the study presented. Sections three and four discuss the most important findings from the analysis. The focus is on the description of changes in Poland's competitive position against the backdrop of the countries under examination and on the factors that determine those developments in the post-accession period (2004-2017).

It is worth stressing that the international competitiveness of economies has been addressed by a number of researchers, but the literature continues to lack studies and analyses covering the V4 countries or the Baltic States. The few studies on the subject include the following publications: Misztal (2009), Falkowski (2018), Kerikmäe, Chochia and Atallah (2018), Molendowski (2017). The article adds value by presenting the most significant results achieved in the process of building the international position of Poland compared to the economies under analysis. The article seems to be a major contribution to bridging the still existing gap in that regard. 


\section{Competitiveness and the international competitive position of an economy - a review of major publications in the literature}

The notion of international economic competitiveness arouses much controversy. While using the category of competitiveness with regard to an enterprise is widely recognised, applying it to the economy as a whole has been frequently challenged.

The concept of the competitiveness of an economy was most fiercely 'attacked' by P. Krugman in his article 'Competitiveness: A Dangerous Obsession' (Krugman 1994, p. 28). He considered drawing an analogy between the competitiveness of corporations and that of countries to be meaningless and contrary to foreign trade theories.

In his criticism, he put forward three arguments:

- corporations that become uncompetitive fall into financial distress over time and, as a result, cease to exist;

- competition between enterprises is a zero-sum game;

- export competitiveness determines the success of small and open economies; therefore, the phenomenon of competitiveness is not a universal idea (cf. Molendowski 2017, pp. 6-8).

But supporters of the concept of economic competitiveness believe it to be a 'modern' approach to fundamental problems of economic development in conditions of globalisation (Reinert 1995, pp. 23-24; Radło 2008, p. 77). In their opinion, it is essential to answer the following questions regarding an economy's international competitiveness: Why do countries vary in socio-economic performance? What are the reasons for such differences? How can national development be shaped and the welfare of the population be improved based on the maximisation of long-term benefits of international trade (Wysokińska 2001, p. 37; Martin 2003, p. 7).

In reply to P. Krugman's concerns about the competitiveness of an economy being unfounded due to the impossibility of defining its bottom line, it is worth looking at the issue as a long-term phenomenon, with structural characteristics (Wziątek-Kubiak 2004, pp. 805-807; Jagiełło 2008, p. 13). It is an element that distinguishes economic competitiveness from business or sectoral competitiveness, representing efficiency-related categories. In the long term, the competitiveness of an economy may be improved through the development of trade specialisation as a result of structural adjustments and quality changes, mostly on account of the technological capacities of the country concerned (Miozzo and Walsh 2006; Alvarez and Marin 2010; Majewska-Bator 2010). Therefore, economic competitiveness is inextricably connected with economic development and must be seen as a dynamic category (Jagiełło 2008, p. 14; Radło 2008, p. 4; Weresa 2008, p. 102).

As regards the second argument put forward by Krugman, national economies are international competitors. It is worth remembering that the comparative advantage 
theory, referred to by Krugman in his criticism, is based on a central assumption of the lack of factor mobility (Kojima and Ozawa 1985, p. 136). According to the concept of locational competition, in conditions of the free movement of production factors, competition is reflected in rivalry for those factors: capital, technological knowledge and skilled labour (Siebert 2006). A more efficient use of production factors, in particular of intangible resources (innovation, cultural standards, organisation and management skills), becomes the foundation for structural adjustments and leads to changes in the competitiveness of economic sectors (Porter 1990; Cho, Moon 1998). Therefore, it can be assumed that countries characterised by similar development levels keep struggling for the provision of convenient conditions for a skilled workforce and for the location of economic activities in innovative industries.

It also seems important to attempt to rebut the argument of the non-universal nature of the concept of economic competitiveness with regard to large countries. Due to ongoing globalisation and the convergence of consumer preferences on a global scale (Mrak 2000), producers from large countries - theoretically, still mainly relying on domestic sales - are exposed to competition from innovative foreign products (Karodia et al. 2014). Although economic growth in a large country is not directly dependent on export competitiveness, in the days of a global economy, international rivalry at the corporation level spreads to national markets. As a result, even a large and industrialised economy cannot ignore competitive pressure from innovation leaders or more cost-effective foreign businesses. Thus, in an open economy, the capabilities to take globalisation-related opportunities but also to cope with threats from international competitors are reflected in job creation in the country concerned and, as a consequence, in economic growth (Howes 2000, p. 180).

The arguments presented above make it possible to justify addressing the competitiveness of national economies in the days of ongoing globalisation. However, it remains open to question how to define the substance of the phenomenon. A snowballing increase in the number of opinions voiced on economic competitiveness has led to chaotic concepts (Gomułka and Czajkowski 2008, p. 16). However, despite terminological incoherence, it is commonly accepted that the notion of the international competitiveness of an economy can be divided into supplementary factor- and outcome-based elements (Radło 2008, pp. 76-78; Adamkiewicz 2019, pp. 30-31).

Outcome-based competitiveness - referred to as the competitive position - represents the place of a country in the global economy in a static approach (Weresa 2008, p. 102). It is reflected in the country's share in international trade, indicating the position achieved in the trade in goods, services, and in international flows of production factors (Misala 2011, p. 80). The situation translates into the country's position and advancement in the modern international division of labour and, consequently, through increased salaries and wages, to the improved welfare of the population (Wysokińska 2001).

Assessing the 'competitive position', as a starting point in competitiveness analysis, makes it possible to estimate the degree of a country's integration into the interna- 
tional division of labour at that time (a static approach). In contrast, an examination of movements of that position over time allows to determine the 'competitive ability' (a dynamic approach). The reasons for the position achieved and determinants of any changes are to be sought 'deeper' - by analysing factor-based competitiveness (Gomułka and Czajkowski 2008, p. 29; Weresa 2008, p. 102).

Each of the categories described above is relative; they must be considered in relation to other countries but also in the context of the development stage of the economy under investigation (for more on the subject see Żmuda and Molendowski 2016, pp. 323-333).

\section{Measures and methods of measuring international economic competitiveness}

In recent years, there have been various measures of the international competitiveness of national economies, and thus a number of measurement methods. It concerns both measuring the competitiveness of a country's economy and its international competitive position in the period under analysis. The determinants of the competitiveness of individual countries have been investigated by many researchers and international centres.

One of them is the International Institute for Management Development (IMD). It publishes its research results in annual reports entitled the World Competitiveness Yearbook, covering several dozen countries. In addition, since 2004, the World Bank has prepared its annual Doing Business reports, which investigate the conditions of pursuing economic activities in the countries under examination. Assessments of international economic competitiveness relatively often rely on the Foreign Direct Investment Confidence Index prepared annually by the consulting firm A.T. Kearney. A country's international competitiveness is also measured by the Human Development Index (HDI), a composite measure of the country's quality of life, published annually by the UNDP.

One of the most comprehensive and most frequently quoted rankings is considered to be that of the international competitiveness of economies: The Global Competitiveness Report. It is the product of a comparative study of economic development conditions in individual countries prepared on an annual basis by the World Economic Forum. ${ }^{2}$ The countries covered are ranked in terms of competitiveness measured by an

2 The report was first published in 1979 and has gradually covered an increasing number of countries (140 in 2017). Initially, it contained a ranking based on the Competitiveness Index designed under the supervision of Prof. J. Sachs, and indicated the foundations of fast economic development in the medium and long term. In 2000, at the initiative of Prof. J. Sachs, a new index calculation methodology was introduced, and the name was changed to the Growth Competitiveness Index, to distinguish it from the current microeconomic competitiveness index used under various names in a number of reports. In 2004, it was replaced by the Global Competitiveness Index, covering not only macroeconomic determinants but also microeconomic factors that facilitiate 
index developed for this purpose. It is calculated on the basis of 114 factors grouped into 12 pillars divided into three categories: basic requirements, efficiency enhancers, as well as innovation and sophistication factors. The first category of factors includes the following pillars: institutions, infrastructure, macroeconomic environment, health, and primary education. The second category comprises the following pillars: higher education and training, goods market efficiency, labour market efficiency, financial market development, technological readiness, and market size. The third category includes business sophistication and innovation (WEF 2017, p. 12). For each pillar, individual countries receive scores of 1 to 7 , where 1 and 7 denote the lowest and the highest possible scores, respectively (WEF 2017, pp. 20-24).

In order to compute the composite indicator of the competitive position, it is essential to place the country concerned in the relevant group that defines its stage of development. The weights assigned to specific pillar groups depend on the value of GDP per capita of the country in question. They are presented in Table 1.

Table 1. Weights of the determinants of the competitive position of a country according to the stage of development (GDP per capita)

\begin{tabular}{|l|c|c|c|c|c|}
\hline \multicolumn{1}{|c|}{ Specification } & $\begin{array}{c}\text { Stage 1: } \\
\text { factor-driv- } \\
\text { en }\end{array}$ & $\begin{array}{c}\text { Transition } \\
\text { from stage 1 } \\
\text { to stage 2 }\end{array}$ & $\begin{array}{c}\text { Stage 2: } \\
\text { efficien- } \\
\text { cy-driven }\end{array}$ & $\begin{array}{c}\text { Transition } \\
\text { from stage 2 } \\
\text { to stage 3 }\end{array}$ & $\begin{array}{c}\text { Stage 3: } \\
\text { innova- } \\
\text { tion-driven }\end{array}$ \\
\hline $\begin{array}{l}\text { GDP per capita } \\
\text { (in USD) }\end{array}$ & $<2000$ & $2,000-2,999$ & $3,000-8,999$ & $9,000-17,000$ & $>17,000$ \\
\hline $\begin{array}{l}\text { Weight for basic } \\
\text { requirements (in \%) }\end{array}$ & 60 & $40-60$ & 40 & $20-40$ & 20 \\
\hline $\begin{array}{l}\text { Weight for } \\
\text { efficiency } \\
\text { enhancers (in \%) }\end{array}$ & 35 & $35-50$ & 50 & 50 & 50 \\
\hline $\begin{array}{l}\text { Weight for } \\
\text { innovation and } \\
\text { sophistication } \\
\text { factors (in \%) }\end{array}$ & 5 & $5-10$ & 10 & $10-30$ & 30 \\
\hline
\end{tabular}

Source: WEF 2017, p. 320.

As follows from the data presented in Table 1, in the WEF ranking, basic requirements are of key importance to economies whose development is mostly based on traditional factors of production (their GDP per capita does not exceed USD 2,000). Efficiency enhancers are crucial for economies mainly driven by investment (GDP per capita of USD 3,000 to USD 17,000). Innovation and sophistication factors are particu-

the assessment of a country's ability of to achieve economic growth. Another modification to the index was introduced in 2008 at the initiative of Prof. M.E. Porter and consisted in the inclusion of productivity determinants, believed to significantly influence the standards of living in individual countries (WEF 2009, pp. 3-7). Data currently published by the WEF according to the methodology concerned cover a period from 2006. In 2019, the WEF ranking methodology was significantly changed, and the most recent results are not comparable to those presented in the previous editions of the report. The $\mathrm{GCl}$ scores were only re-estimated according to the new guidelines for 2017 (WEF 2019, pp. 1-3). 
larly vital to countries whose development is innovation-driven. They are countries at the top (third) stage of economic development (their GDP per capita exceeds USD 17,000). It is worth emphasising that efficiency enhancers were assigned relatively the highest weight among the determinants of a country's competitive position. At the same time, basic requirements play a relatively significant role in defining the competitive position of the lowest-income countries. The classification of the countries covered by the presented analysis based on those assumptions is shown in Table 2.

Table 2. Classification of the EU-10 by stage of development with GDP per capita thresholds

\begin{tabular}{|l|l|l|}
\hline \multirow{2}{*}{ Stage of development } & \multicolumn{2}{|c|}{ Year } \\
\cline { 2 - 3 } Stage 2: efficiency-driven & $\begin{array}{l}|c| \\
\text { Bulgaria, Lithuania, Latvia, } \\
\text { Poland, Romania, Slovakia }\end{array}$ & Bulgaria \\
\hline $\begin{array}{l}\text { Transition from stage 2 } \\
\text { to stage 3 }\end{array}$ & Czech Republic, Estonia, Hungary & $\begin{array}{l}\text { Lithuania, Latvia, Poland, } \\
\text { Romania, Hungary, Slovakia }\end{array}$ \\
\hline Stage 3: innovation-driven & Slovenia & Czech Republic, Estonia, Slovenia \\
\hline
\end{tabular}

Source: prepared by the author based on WEF 2008, p. 9; WEF 2018, p. 320.

It follows from the above presentation that the weights in the 2006-2018 World Economic Forum (WEF) Reports considerably changed for particular determinants of the international competitive positions of the EU-10 economies. According to that assumption, in 2006, the majority (six) of the countries covered would have shaped their competitive positions mostly based on efficiency enhancers (50\%) and basic requirements (40\%). In contrast, in 2018, six of the countries under analysis should show significantly diminished importance of basic requirements (from $40 \%$ to $30 \%$ ) in favour of innovation and sophistication factors (from 10\% to 30\%), while in three of them, the most essential role, in addition to efficiency enhancers (50\%), should be played by innovation and sophistication factors (30\%).

\section{Changes in the competitive position of Poland against the backdrop of the Visegrad Group countries and the Baltic States}

According to the results of the economic competitiveness studies carried out by the WEF, in the post-accession period, the international competitive positions of Poland, the V4 and the BS3 showed significant changes (cf. Table 3). While in the first years after accession Poland ranked the lowest $\left(60^{\text {th }}\right)$ among the countries covered, the following years witnessed an almost steady rise. It is worth emphasising that its position showed particular improvement in the first years after accession (2005-2007). Over three years, the Polish economy moved to $45^{\text {th }}$ place (up as many as 15 spots). During the global crisis, that positive trend was arrested, but from 2013 (to 2016), a marked 
advancement was noted again. It is worth emphasising that throughout the period in question (until 2018), Poland improved its rank by as many as 21 spots.

An important element of the analysis presented was to compare the scores obtained by Poland with those of the other countries covered. It is common knowledge that those were the most successful transition economies among all the Central and Eastern European countries. Joining the EU triggered sustainable changes and building firm and stable foundations for further development. However, they varied rather widely in terms of competitiveness scores (cf. Table 3 and Chart 1). At the beginning of the period covered, Poland was assessed relatively the worst.

Poland's place differed considerably from the positions of the Visegrad Group (V4) countries. At the time, the Czech Republic, Hungary and Slovakia ranked much higher $\left(40^{\text {th }}, 39^{\text {th }}\right.$ and $43^{\text {rd }}$ place, respectively). The Baltic States were considerably ahead of Poland as well, with the WEF ranking Estonia, Latvia and Lithuania $20^{\text {th }}, 36^{\text {th }}$ and $44^{\text {th }}$, respectively.

In the following years, until 2007, Poland continued to be ranked lower than the other V4 countries and the Baltic States. In 2008, Hungary fell below Poland, joined by Slovakia, Latvia and Lithuania in 2009. Between 2010 and 2012, Poland ranked higher than five out of the seven countries covered. The same situation was observed until the end of the analysed period (2017). As a result, in 2017 only Estonia and the Czech Republic ranked higher than Poland. Therefore, ranking 39 ${ }^{\text {th }}$, Poland showed the greatest advancement (in comparison with the countries under examination), up as many as 21 spots (by 0.61). ${ }^{3}$ Apart from Poland, only the Czech Republic improved its position (by nine places and 0.22). At the same time, six countries fell in the ranking, including Hungary (down 21 spots), Slovakia (down 16 spots) and Slovenia (down 15 spots).

As a result of those developments, in 2017, Poland joined the WEF ranking leaders (the Czech Republic, Estonia and Lithuania) among the countries under analysis.

Table 3. Global Competitiveness Index scores of the Polish economy against the backdrop of the V4 and BS3 economies in 2006-2017*

\begin{tabular}{|c|c|c|c|c|c|c|c|c|c|c|c|c|c|c|}
\hline \multirow{2}{*}{$\begin{array}{c}\text { Report } \\
\text { edition }\end{array}$} & \multicolumn{2}{|c|}{ PL } & \multicolumn{2}{c|}{ CZ } & \multicolumn{2}{c|}{ HU } & \multicolumn{2}{c|}{ SK } & \multicolumn{2}{c|}{ EE } & \multicolumn{2}{|c|}{ LT } & \multicolumn{2}{c|}{ LV } \\
\hline $2004 / 2005$ & 60 & 3.98 & 40 & 4.55 & 39 & 4.56 & 43 & 4.43 & 20 & 5.08 & 36 & 4.57 & 44 & 4.43 \\
\hline $2005 / 2006$ & 51 & 4.00 & 38 & 4.42 & 39 & 4.38 & 41 & 4.31 & 20 & 4.95 & 43 & 4.30 & 44 & 4.29 \\
\hline $2006 / 2007$ & 45 & 4.39 & 31 & 4.67 & 38 & 4.49 & 36 & 4.54 & 26 & 4.82 & 39 & 4.49 & 44 & 4.47 \\
\hline $2007 / 2008$ & 51 & 4.28 & 33 & 4.58 & 47 & 4.35 & 41 & 4.45 & 27 & 4.74 & 38 & 4.49 & 45 & 4.41 \\
\hline $2008 / 2009$ & 53 & 4.28 & 33 & 4.62 & 62 & 4.22 & 46 & 4.40 & 32 & 4.67 & 44 & 4.45 & 54 & 4.26 \\
\hline $2009 / 2010$ & 46 & 4.33 & 31 & 4.67 & 58 & 4.22 & 47 & 4.31 & 35 & 4.56 & 53 & 4.30 & 68 & 4.06 \\
\hline $2010 / 2011$ & 39 & 4.51 & 36 & 4.57 & 52 & 4.33 & 60 & 4.25 & 33 & 4.61 & 47 & 4.38 & 70 & 4.14 \\
\hline $2011 / 2012$ & 41 & 4.46 & 38 & 4.52 & 48 & 4.36 & 69 & 4.19 & 33 & 4.62 & 44 & 4.41 & 64 & 4.24 \\
\hline $2012 / 2013$ & 41 & 4.46 & 39 & 4.51 & 60 & 4.30 & 71 & 4.14 & 34 & 4.64 & 45 & 4.41 & 55 & 4.35 \\
\hline
\end{tabular}

3 For more on the subject see: Boguszewski 2016, pp. 21-28. 


\begin{tabular}{|c|c|c|c|c|c|c|c|c|c|c|c|c|c|c|}
\hline \multirow{2}{*}{$\begin{array}{c}\text { Report } \\
\text { edition }\end{array}$} & \multicolumn{2}{|c|}{ PL } & \multicolumn{2}{c|}{ CZ } & \multicolumn{2}{c|}{ HU } & \multicolumn{2}{c|}{ SK } & \multicolumn{2}{c|}{ EE } & \multicolumn{3}{c|}{ LT } & \multicolumn{2}{c|}{ LV } \\
\hline $2013 / 2014$ & 42 & 4.46 & 46 & 4.43 & 63 & 4.25 & 78 & 4.10 & 32 & 4.65 & 48 & 4.41 & 52 & 4.40 \\
\hline $2014 / 2015$ & 43 & 4.48 & 37 & 4.53 & 60 & 4.28 & 75 & 4.15 & 29 & 4.71 & 41 & 4.51 & 42 & 4.50 \\
\hline $2015 / 2016$ & 41 & 4.49 & 31 & 4.69 & 63 & 4.25 & 67 & 4.22 & 30 & 4.74 & 36 & 4.55 & 44 & 4.45 \\
\hline $2016 / 2017$ & 36 & 4.56 & 31 & 4.72 & 69 & 4.20 & 65 & 4.28 & 30 & 4.78 & 35 & 4.60 & 49 & 4.45 \\
\hline $2017 / 2018$ & 39 & 4.59 & 31 & 4.77 & 60 & 4.33 & 59 & 4.33 & 29 & 4.85 & 41 & 4.58 & 54 & 4.40 \\
\hline $2018 / 2004$ & 21 & 0.61 & 9 & 0.22 & -21 & 0.23 & -16 & 0.10 & -9 & 0.23 & -5 & 0.01 & -10 & 0.03 \\
\hline
\end{tabular}

${ }^{*}$ A - Rank, B - GCl score

Source: prepared by the author based on WEF 2015, WEF 2018.

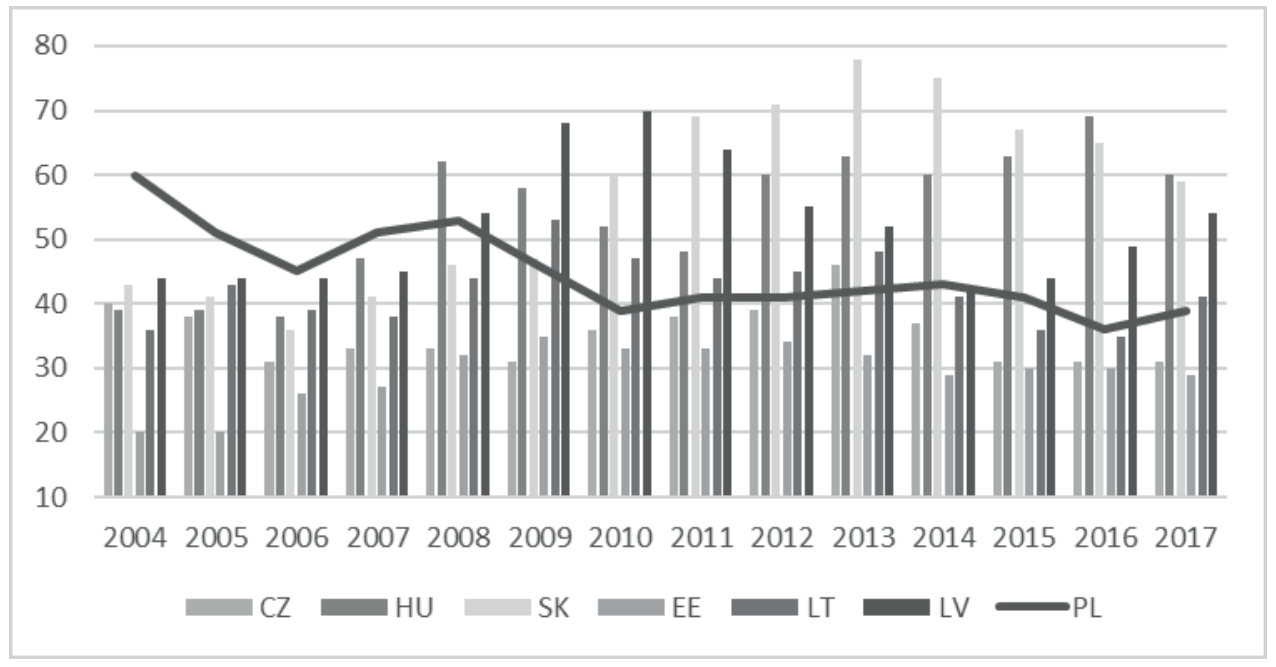

Chart 1. Changes in the competitive position of Poland against the backdrop of the Baltic States and the V4 countries (in 2006-2017)

Source: prepared by the author based on the data used in Table 3.

To recapitulate, throughout the period 2004-2017, the most favourable situation in terms of international competitive position was observed for the Czech Republic and Estonia, in addition to Poland. However, the countries in question were unable to match the achievement of the Polish economy. In contrast, the other two Baltic States, as well as Hungary and Slovakia, dropped in the ranking in 2017 compared to 2004, even though their GCI (Global Competitiveness Index) scores showed some improvement. 


\section{Determinants of the competitive position of Poland (against the backdrop of the Visegrad Group countries and the Baltic States)}

As already mentioned above, it follows from The Global Competitiveness Reports prepared by the World Economic Forum that the analysed countries should show a much greater significance of efficiency enhancers as well as innovation and sophistication factors in shaping their competitive positions. While in 2006 basic requirements played a relatively important role, by 2017 they had diminished in importance (in favour of efficiency enhancers and innovation and sophistication factors). In the analysis presented, it was decided to verify whether such a trend could be observed. The examination was based on the data shown in Table 4.

It follows from the data presented in Table 4 that in 2006, the competitive positions of the V4 countries were mostly driven by basic requirements (pillars). The GCI score of the group in question was 4.62, far above the overall GCI score of 4.39 (with a difference of 0.24 ). A similar situation was also observed in the other countries covered, although basic requirements contributed relatively the most to the overall GCI score in the case of Estonia (the respective difference was 0.46 ).

Efficiency enhancers (sub-index 2) represented the second most significant group of factors in Poland, as well as in all the countries under examination. They played relatively the greatest role (which must be assessed positively) in Estonia, the Czech Republic and Slovakia. As regards Poland, the GCI score for this group of factors was similar to the overall GCI score.

The pillars included in group 3 (innovation and sophistication factors) contributed relatively the least to the scores obtained by all the analysed countries. It was particularly observed in Latvia, Estonia, Slovakia, Poland and Lithuania. 


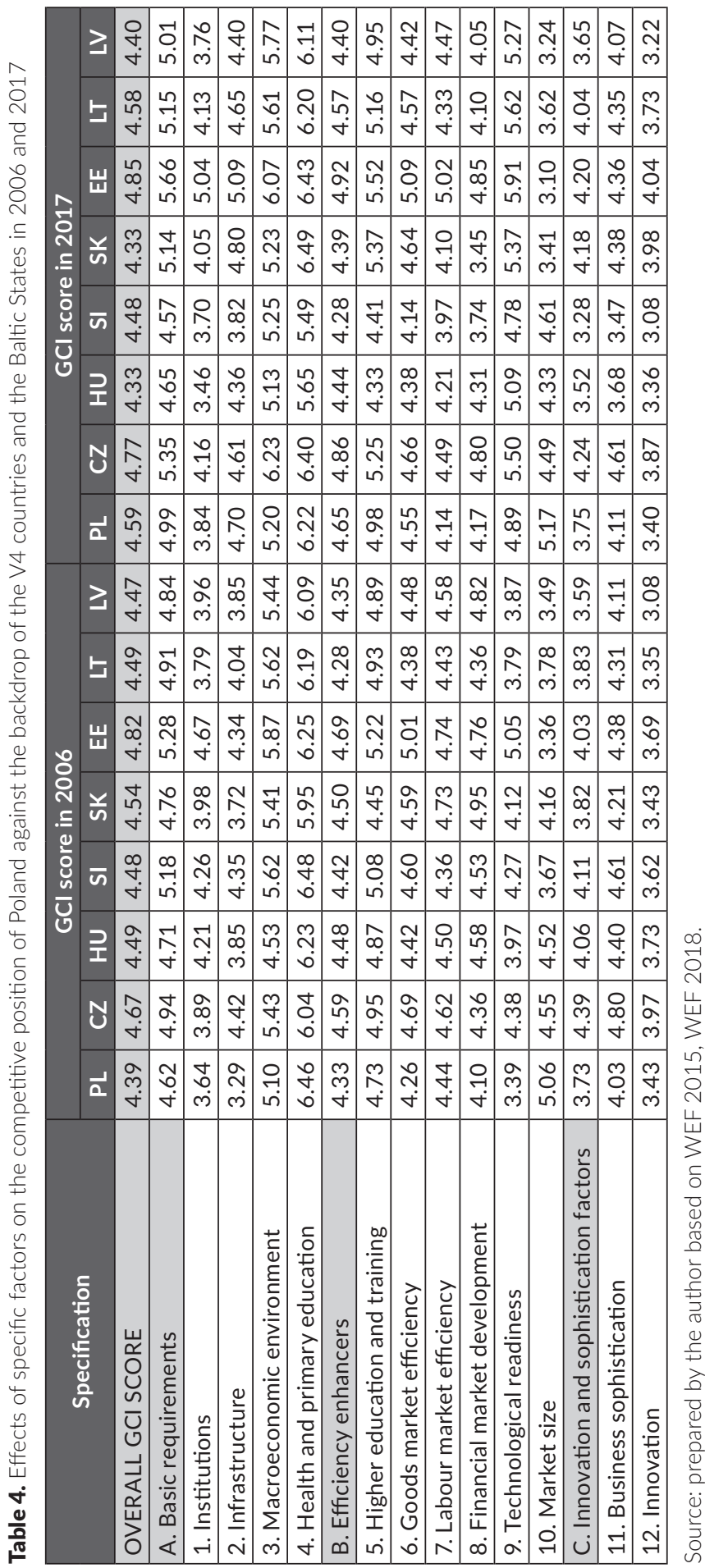



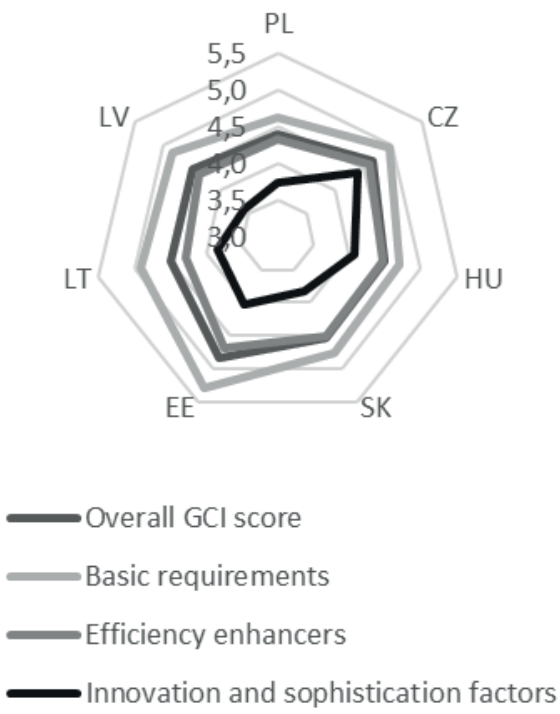

Chart 3. Determinants of the competitive position of Poland against the backdrop of the other $\vee 4$ countries and the Baltic States in 2006

Source: prepared by the author based on Table 4.

Interestingly, it follows from the data presented in Table 4 that in 2006, in addition to market size, Poland's competitive position was mostly driven by health and primary education, higher education and training, as well as, labour market efficiency and innovation, although to a much lesser degree. Those pillars were classified as basic requirements or efficiency enhancers.

Obviously, in such studies, it is particularly crucial to examine long-term trends. Therefore, the analysis presented attempted to identify the most important trends characteristic of developments in the competitive positions of the countries covered in 2017 against 2006. Those changes are evident in the comparison of Charts 3 and 4.

The comparison of Charts 3 and 4 (and the data presented in Table 4) clearly shows an advancement in Poland's competitive position, not only in terms of the overall score but also with regard to basic requirements. The score for basic requirements (4.99) exceeded the overall GCI score (4.59). It means that the factors in question significantly gained in importance in shaping the competitive position and remained key drivers. It is worth stressing that in accordance with the WEF recommendations, it would have been more desirable to reduce the contribution of basic requirements to the competitive positions of countries at a similar stage of development to that of Poland (cf. Tables 2 and 3).

Changes in the score for efficiency enhancers must be evaluated as favourable. In 2004-2017, the score for the sub-index (4.65) rose by 0.32, whereas the overall GCI score went up by 0.21 . Therefore, the trend was consistent with the WEF recommendations. But the score for innovation and sophistication factors remained much low- 
er (3.75) than the overall GCI score (merely 0.03 above the 2006 level). With regard to the pillars in question, Poland recorded a relative deterioration rather than any improvement.

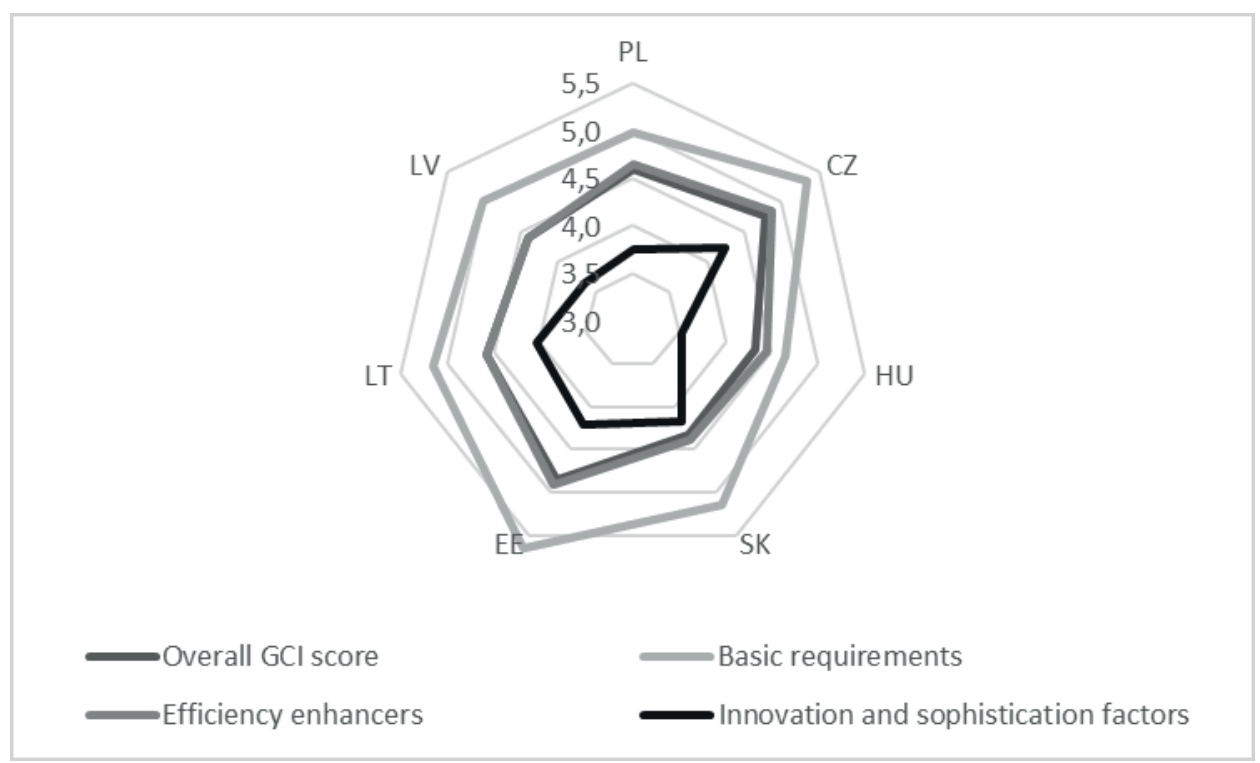

Chart 4. Determinants of the competitive position of Poland against the backdrop of the other V4 countries and the Baltic States in 2017

Source: prepared by the author based on Table 5.

To recapitulate, in 2006-2017 Poland's competitive position only showed improvement with regard to the effects of efficiency enhancers, whereas changes in the contributions of basic requirements and innovation and sophistication factors must be assessed as negative trends.

A similar situation was also observed in the other countries covered. It must be particularly emphasised that the score for basic requirements increased considerably in relation to the overall GCI score (whereas the WEF recommends reducing the role of the pillars in question). The growth was the most evident for the Czech Republic (by 0.20), Slovakia (0.17) and Estonia (0.17). As regards Lithuania and Latvia, their respective scores for basic requirements followed nearly the same trends as the overall GCI scores. Only Hungary recorded a marked decline in the score for basic requirements compared to the overall GCI score (by 0.27 ).

In the group of efficiency enhancers (whose contribution should be increased, according to the WEF recommendations), all the countries covered noted improved their scores. In the period in question, the most significant advancements were noted for Poland (up by 0.32), Lithuania (by 0.29), the Czech Republic (by 0.27) and Estonia (by 0.23 ). As regards the other countries (Hungary, Slovakia and Latvia), their respective GCI scores remained basically unchanged. 
At the same time, in the group of innovation and sophistication factors (the WEF recommends increasing their role), the most distinct improvements in score were observed for Slovakia (by 0.36), Lithuania (by 0.21 ), and Estonia (by 0.17 ). The scores for Poland and Latvia remained virtually unchanged, whereas Hungary and the Czech Republic showed a decrease (by 0.54 and 0.15 , respectively).

To recapitulate, the developments observed in the countries covered varied rather widely. Favourable changes concerning basic requirements only occurred in Hungary. Positive changes in efficiency enhancers were noted for Poland, Lithuania, the Czech Republic and Estonia. In the group of innovation and sophistication factors, marked improvements were only observed for Slovakia, Lithuania and Estonia. Simultaneously, the most adverse changes in basic requirements took place in Poland, the Czech Republic, Slovakia and Estonia; with regard to efficiency enhancers - in the case of Hungary, Slovakia and Latvia; in terms of innovation and sophistication factors - for Hungary and the Czech Republic.

\section{Summary and conclusions}

It follows from the review of major publications in the literature presented in the article that the competitiveness of an economy should be described dynamically, from the angle of the development of available (domestic and foreign) production factors, the ability to take opportunities related to ongoing globalisation, and the adaptability of businesses, sectors and the economy as a whole to the changing conditions in the external environment, thus - the achievement of development objectives. Such an approach to economic competitiveness was adopted by the authors of the Global Competitiveness Reports prepared by researchers associated with the World Economic Forum.

Thanks to their accession to the European Union, the majority of the new Member States experienced rapid economic growth accompanied by restructuring and modernisation. It considerably improved the international competitive positions of their economies.

Obviously, in investigations of changes in the competitive positions of economies and their determinants, a particular focus is on the study of long-term trends. Therefore, the analysis attempted to identify the most important trends characteristic of developments in the competitive positions of the countries covered in the period 20042017 and in their determinants in the period 2006-2017.

In the post-accession period, Poland appeared to be the most successful in improving the international competitive position of its economy among the countries under examination (moving up in the WEF ranking by 21 spots, from $60^{\text {th }}$ place in 2006 to $39^{\text {th }}$ in 2017). In the Visegrad Group (V4), the most favourable situation in that regard was noted for the Czech Republic (up nine spots). The other V4 countries experienced a deterioration (Hungary - down 21 spots, Slovakia - down 19 spots). As regards the 
Baltic States (BS3), the most advantageous situation was noted in the case of Lithuania and Estonia. However, Estonia's rank dropped (as many as nine spots). Deteriorated ranks were also noted by Lithuania and Latvia (by 5 and 10 spots respectively). Thus, the countries in question were unable to match the achievement of Poland.

An important element of the presented analysis was an attempt at verifying the assumption that the V4 countries and the Baltic States should already (as recommended by the WEF) increasingly rely on building their international competitive positions mostly on efficiency enhancers and also, to a growing degree, on innovation and sophistication factors.

The analysis suggests that in the period in question, the scores for efficiency enhancers showed an upward trend in almost all analysed countries (with the exception of Slovakia and Hungary). Characteristically, however, in the case of Poland, efficiency enhancers gained in importance to the greatest degree.

The role of innovation and sophistication factors was rather limited in the countries covered. In this regard, in 2017 the situation was nearly the same as in 2006. Therefore, the trends actually observed were different from those recommended by the WEF experts.

An essential conclusion to be drawn from the analysis is that in 2017, these countries relied on basic requirements in shaping their competitive positions, contrary to the WEF recommendation to reduce their role.

The examination unambiguously shows that in the years to come, Poland and the other countries under review - to a greater degree than before - should build their competitive positions based on efficiency enhancers as well as on innovation and sophistication factors, especially on those previously underestimated.

\section{References}

Adamkiewicz, H. (2019), Konkurencyjność międzynarodowa krajów, Wydawnictwo Politechniki Gdańskiej, Gdańsk.

Alvarez, I., Marin, R. (2013), FDI and technology as levering factors of competitiveness in developing countries, "Journal of International Management", 19 (3), pp. 232-246, https://doi.org/10.1016/j.intman.2013.02.005

Boguszewski, P. (2016), Globalny raport konkurencyjności 2016-2017 Światowego Forum Gospodarczego, NBP, Warszawa.

Cho, D., Moon, H. (1998), A nation's international competitiveness in different stages of economic development, "Advances in Competitiveness Research", 6 (1), pp. 5-19.

Falkowski, K. (2018), Competitiveness of the Baltic States in International High-Technology Goods Trade, "Comparative Economic Research. Central and Eastern Europe”, 21 (1), pp. 25-43. https://doi.org/10.2478/cer-2018-0002

Gomułka, M., Czajkowski, Z. (2008), Konkurencyjność międzynarodowa - pojęcie i metodologia pomiaru. Materiały do dyskusji, [in:] W. Bieńkowski, M.A. Weresa 
(eds.), Czynniki i miary międzynarodowej konkurencyjności gospodarek $w$ kontekście globalizacji - wstępne wyniki badań, SGH, Warszawa.

Howes, C. (2000), U.S. Competitiveness and Economic Growth, [in:] C. Howes, A. Singh (eds.), Competitiveness Matters: Industry and Economic Performance in the U.S., The University of Michigan Press, Michigan, https://doi.org/10.3998/mpub.16353

Jagiełło, E.M. (2008), Strategiczne budowanie konkurencyjności gospodarki, Poltext, Warszawa.

Karodia, A.M., Soni D., David J.E. (2014), International Competitiveness, Globalization and Technology for Developing Countries, "Singaporean Journal of Business Economics and Management Studies”, 12 (9), pp. 25-34, https://doi.org/10.12816 /0003902

Kerikmäe, T., Chochia, A., \& Atallah, M. (2018), The Baltic States in the European Union [in:] Oxford Research Encyclopaedia of Politics, Published online, April 2018. https:// dx.doi.org/10.1093/acrefore/9780190228637.013.186

Kojima, K., Ozawa, T. (1985), Toward a Theory of Industrial Restructuring and Dynamic Comparative Advantage, "Hitotsubashi Journal of Economics", 26, pp. 133-145.

Krugman, P. (1994), Competitiveness: A Dangerous Obsession, "Foreign Affairs”, 73 (2), pp. 28-44, https://doi.org/10.2307/20045917

Majewska-Bator, M. (2010), Rozwój endogenicznej przewagi w handlu międzynarodowym a proces zmniejszania luki technologicznej, Wydawnictwo Naukowe UAM, Poznań.

Martin, R. (2003), A Study on the Factors of Regional Competitiveness. Final report for The European Commission Directorate-General Regional Policy, University of Cambridge, Cambridge.

Miozzo, M., Walsh, V. (2006), International Competitiveness and Technological Change, Oxford University Press, New York, https://doi.org/10.1093/acprof:oso/978019925 9236.001.0001

Misala, J. (2011), Międzynarodowa konkurencyjność gospodarki narodowej, PWE, Warszawa.

Misztal, P. (2009), International competitiveness of the Baltic States in the transformation period: Lithuania, Latvia and Estonia, 8 (3), pp. 21-35. http://www.transfor mations.knf.vu.lt/18/ge18.pdf (accessed: 2.11.2020).

Molendowski, E. (2017), An Internationally Competitive Economy: A Comparison of Poland And The Visegrad Group Countries In The Post-Accession Period, "Comparative Economic Research. Central and Eastern Europe”, 20 (4), pp. 5-21, https://doi .org/10.1515/cer-2017-0025

Molendowski, E., Folfas, P. (2019), Effects of the Pillars of Competitiveness on the Competitive Positions of Poland and of The Visegrad Group Countries in the Post-Accession Period, "Comparative Economic Research. Central and Eastern Europe", 22 (2), pp. 55-67, https://doi.org/10.2478/cer-2019-0012

Mrak, M. (2000), Globalization: Trends, Challenges and Opportunities in Countries in Transition, IDO, Vienna.

Porter, M.E. (1990), The Competitive Advantage of Nations, The Free Press, New York, http://www.economie.ens.fr/IMG/pdf/porter_1990_-_the_competitive_advantage _of_nations.pdf (accessed: 2.11.2020). 
Radło, M.J. (2008), Międzynarodowa konkurencyjność gospodarki. Uwagi na temat definicji, czynników i miar, [in:] W. Bieńkowski, M.A. Weresa (eds.), Czynniki i miary międzynarodowej konkurencyjności gospodarek w kontekście globalizacji - wstępne wyniki badań, SGH, Warszawa, http://www.radlo.org/mkg.pdf (accessed: 2.11.2020).

Reinert, E. (1995), Competitiveness and its predecessors - a 500-year cross-national perspective, "Structural Change and Economic Dynamics", 6, pp. 23-42, https://doi.org /10.1016/0954-349X(94)00002-Q

Siebert, H. (2006), Locational Competition: A Neglected Paradigm in the International Division of Labour, "The World Economy”, 29 (2) pp. 137-159, https://doi.org/10.11 11/j.1467-9701.2006.00775.x

WEF (2008), The Global Competitiveness Report 2008-2009, World Economic Forum, Geneva.

WEF (2009), The Global Competitivenes Report 2009-2010, World Economic Forum, Geneva.

WEF (2015), The Global Competitiveness Index Historical Dataset (C) 2005-2015, World Economic Forum, Geneva.

WEF (2017), The Global Competitiveness Report 2016-2017, World Economic Forum, Geneva.

WEF (2018), The Global Competitiveness Report 2018, World Economic Forum, Geneva.

WEF (2019), The Global Competitiveness Report 2019, World Economic Forum, Geneva.

Weresa, M.A. (2008), Definicje, determinanty oraz sposoby pomiaru konkurencyjności krajów, „Prace i Materiały”, 284, SGH, Warszawa, pp. 98-108.

Wołkonowski, J. (2019), The Beta-Convergence of the EU-10 Countries and Regions in the Years 2004-2015, "Comparative Economic Research. Central and Eastern Europe”, 22 (2), pp. 87-104, https://doi.org/10.2478/cer-2019-0014

Wysokińska, Z. (2001), Konkurencyjność w międzynarodowym i globalnym handlu technologiami, PWN, Warszawa.

Wziątek-Kubiak, A. (2004), Kontrowersje wokół konkurencyjności w teorii ekonomii, "Ekonomista", 6, pp. 805-822.

Żmuda, M., Molendowski, E. (2016), W poszukiwaniu istoty konkurencyjności gospodarki narodowej: studium interdyscyplinarne, "Finanse, Rynki Finansowe, Ubezpieczenia” 3 (81), pp. 323-333, https://doi.org/10.18276/frfu.2016.81-28 


\section{Pozycja konkurencyjna gospodarki Polski (na tle krajów Grupy Wyszehradzkiej oraz Krajów Bałtyckich) - zmiany i czynniki ją determinujące w okresie poakcesyjnym}

Artykuł jest prezentacją wyników analizy, w ramach której podjęto próbę porównania zmian pozycji konkurencyjnej Polski na tle państw Grupy Wyszehradzkiej (GW-4) oraz Krajów Bałtyckich (KB-3) w okresie poakcesyjnym (lata 2006-2017). Należy podkreślić, że tego typu badanie nie było jeszcze szerzej prezentowane w dostępnej literaturze. Artykuł może być więc ważnym uzupełniniem tej luki.

W badaniu zastosowano metodę analizy porównawczej danych wtórnych, dotyczących wskaźników konkurencyjności gospodarki oraz czynników ją determinujących wyodrębnionych w Raportach "Global Competitiveness Report”, opracowywanych przez Światowe Forum Ekonomiczne. Ważnym elementem prezentowanej analizy było podjęcie próby zidentyfikowania najważniejszych czynników determinujących te zmiany. Artykuł kończy zestawienie najważniejszych wniosków wynikających z prezentowanej analizy. Analiza potwierdziła, że badane kraje cechowały się dość istotnymi różnicami w zakresie poprawy ich pozycji konkurencyjnej w okresie poakcesyjnym.

Słowa kluczowe: międzynarodowa konkurencyjność gospodarki, efekty członkostwa w UE, Kraje Bałtyckie, państwa Grupy Wyszehradzkiej, Nowe Państwa Członkowskie UE 